\title{
An African Interpretation of Paul's Understanding of The Holy Spirit
}

\author{
Dr. David T. Ejenobo, Associate Professor \\ Department of Religious Studies and Philosophy \\ Delta State University, Abraka, Nigeria.
}

doi: 10.19044/esj.2016.v12n32p426 URL:http://dx.doi.org/10.19044/esj.2016.v12n32p426

\begin{abstract}
The doctrine of the trinity has generated a lot of controversies down the centuries among New Testament scholars. The problem generated by scholars to dissect the Personhood of God has resulted in various shades of interpretations on the relationship between God the Father, the Son and the Holy Spirit. It is against this background that this paper seeks to examine Paul's understanding of the Holy Spirit viewed against the backdrop of the doctrine of the Trinity. This study adopted the textual critical method to examine the various nuances of Paul's allusion to the Holy Spirit with a view to situating them within a proper understanding of the concept of the trinity. The author discovered that for Paul there is no personality distinction between God the Father, the Son and the Holy Spirit, since man encounters these "persons" in the spiritual realm. Applying the hermeneutical method of contextual interpretation, the author is of the opinion that for the African, conceptualizing God within the realm of the Spirithood of God would be a more practical way of describing the activities of God the Father, the Son and the Holy Spirit than the Western conceptualization of the Three Persons in on Godhead.
\end{abstract}

Keywords: Holy Spirit, Trinity, Spirithood of God

\section{Introduction}

Beginning with the Arian controversy, the doctrine of the Trinity has been subjected to all kinds of interpretations. Even though the Council of Nicea in $325 \mathrm{AD}$ tried to address the issue of equality of the three persons in the Godhead, it was not able to resolve the main issue of the generic relationship between God the Father and God the Son. Subsequent theological discussions on the Trinitarian question have tended to either support the position of the Council or oppose it. 
Most New Testament scholars will agree with the position that the epistles of Paul provide more texts for a theological discuss on the Trinitarian question than the four Gospels. In his book An Afrocentric interpretation of the Holy Spirit in Pauline Theology the author carried out a more detailed evaluation of this subject. In this paper an attempt has been made to examine the various ways in which Paul understood and used the phrase "The Holy Spirit." Traditionally, the Holy Spirit is referred to as the third "Person" of the Trinity. But we shall see that rather than understanding the Holy Spirit as a distinct person from the other persons of the Trinity, Paul actually understood the Holy Spirit as God so that when he used the phrase "the Holy Spirit" he was not thinking essentially of another person in the Godhead, but the Godhead itself.

\section{Paul's Understanding Of The Holy Spirit}

\section{A. The Holy Spirit as God}

P. E. Hughes (42) has observed that in the thought of the New Testament writers, and more so in Paul, the Christian experience of anointing, sealing, and receiving the earnest of our inheritance are all associated with the operation of the Holy Spirit. In other words, almost always when Paul talks of the work of anointing, sealing and having the assurance of salvation, he has in mind the anointing of the Holy Spirit, the sealing with the Holy Spirit and receiving the earnest of our inheritance through the indwelling Spirit. Thus the Holy Spirit is God in action towards men, bringing them into the new dimension of spiritual reality manifested in the life and ministry of Jesus Christ.

Some scholars like Arthur Pink would ascribe personality to the Holy Spirit with reference to His understanding, willing and loving characteristics (cf. I Cor. 2:10; 12:11; Rom. 15:30; I Tim. 4:1; Rom. 8:26, 16; I Cor. 6:11) (11). However, it appears that such attempts at arguing for a personality of the Holy Spirit distinct from that of God is based on the fact that the Holy Spirit is considered to be different from the God with whom Christians are expected to relate. This is not the case. Three passages in which certain aspects of the characteristics of the Holy Spirit are mentioned should be examined to bring out the point that at any such times when reference is made to the Holy Spirit, God is always at the back of Paul's mind, pointing out the essential unity between the Holy Spirit and God.

\section{Romans 8:26:}

In this text Paul assures his readers that the Spirit helps them in their weaknesses; for they know not how to pray as they ought. However, the Spirit Himself pleads for them in yearnings that can find no words, and the 
Searcher of hearts knows what the Spirit's meaning is, because His intercessions for the saints are in harmony with God's will.

It has been concluded from this verse that the Holy Spirit who pleads for Christians is distinct from the God to whom they pray. The meaning of this passage, however, appears to be that it is the Holy Spirit who actually enables Christians to offer prayers that are in line with God's will for their lives. In other words, the Holy Spirit who enables Christians to pray is no different from the God to whom they pray. Prayer is an activity carried out in the spiritual realm. Thus, the prayers the Holy Spirit enables Christians to pray are actually prayers that God would have them offer.

The idea behind this concept can not be divorced from the consciousness of the fact that after the fall of man, he lost certain elements of God-consciousness which makes him to will things opposed to the will of God (Gal. 5:17). However, at conversion, when the Holy Spirit touches a person, giving him a new God-consciousness, that person is now enabled to know the things of God, and thus he is able to pray the prayers of God (cf. Col. 3:1f).

\section{Corinthians 12:11:}

When Paul opines in I Corinthians 12:11 that the Holy Spirit allots spiritual gifts to each individual as He pleases, it is possible to substitute the word "God" for the Holy Spirit and still retain the meaning of the verse: "But all these results are brought about by one and the same God, our father, allotting them to each individually as He pleases." Paul perhaps did not use the word "God" here because, as we noted earlier, when Paul talks about the action of God upon the human consciousness, he always thinks of the Holy Spirit. In other words, to say that the Holy Spirit gives spiritual gifts is to say that God gives such gifts. The suggestion that some gifts are of the Holy Spirit and others of God the Father can hardly find justification when it is observed that spiritual gifts are given in the spiritual realm; and in the spiritual realm, the Holy Spirit is no different from God the Father. Thus, strictly speaking, the gifts which the Holy Spirit gives are the gifts which God the Father gives.

\section{Romans 9:1:}

Writing in Romans 9:1 Paul says: "I say the truth in Christ, I lie not, my conscience also bearing me witness in the Holy Ghost” (KJV). The NIV translates this verse thus: "I speak the truth in Christ - I am not lying, my conscience confirms it in the Holy Spirit." Weymouth puts it this way: "I am telling you the truth as a Christian - it is no falsehood, for my inspired conscience bears me out.” From these translations, it becomes difficult to argue for a personality of the Holy Spirit distinct from that of Christ. Paul's 
being in Christ is practically demonstrated by the fact that he does not tell lies because he believes himself to be under the influence of the Holy Spirit who is also the Spirit of Christ.

These passages only serve to complement what has been said above. The point to note is that for Paul, God in His action towards men is experienced as Spirit, the Holy Spirit, so that more often than not, the term Holy Spirit is actually used as a synonym for God.

\section{B. The Dispensation of the Spirit}

For Paul, it appears, after the ascension of Jesus Christ, the age in which we now live is the age of the Holy Spirit. This does not mean that the Holy Spirit was not active in the life of the historical Jesus. However, as is also apparent in the Acts of the Apostles, the resurrection of Jesus Christ ushered in a new dimension in the spiritual experience of men with God. This period as distinct from the preceding one was marked by the visible advent of the Holy Spirit on the day of Pentecost in Acts of the Apostles Chapter 2.

Hans Dieter Betz (277), commenting on Galatians 5:16, points out two important facts worthy of note in this connection. The verse itself reads: "I say then, let your lives be guided by the Spirit, and then you will not fulfill the cravings of your lower nature.” Concerning this verse, Betz makes the following observations.

1. The imperative $\pi v \varepsilon v \mu \alpha \tau \imath \pi \varepsilon \rho \imath \pi \alpha \varepsilon \omega$ (walk by the spirit) sums up Paul's concept of the Christian life. In other words, the concept of $\pi \varepsilon \rho i \pi \alpha \tau \varepsilon \omega$ describes the Christian life by one of the more important terms of ancient anthropology, which expresses the view that human life is essentially a "way of life." In other words, when Paul used the word $\pi \varepsilon \rho i \pi \alpha \tau \varepsilon \omega$, he had in mind a manner of living that has some distinguishing characteristics.

2. However, there is a promise in the verse: "You will not carry out the desires of the flesh." This promise depends upon the preceding imperative. That is, the imperative "walk by the Spirit" will eventually lead to a situation where one will not carry out the desires of the flesh.

When these two concepts are put together, one can surmise that Paul's conception of the human life can be summed up in the two phrases: life in the flesh and life in the Spirit. The life lived in the Spirit is that which has the Holy Spirit at the driver's seat. That life is the Christian life. That is the life exemplified in the life and ministry of Jesus which every man is expected emulate. Paul's emphasis in all his writings is that it is the Holy Spirit who enables men to live that Christ-life.

If the whole intent of the Gospel of Jesus Christ is to show mankind how, under the influence of the Holy Spirit, they can live lives pleasing to God, then only the Holy Spirit can actually perform this meaningfully in the 
lives of men. However, fully conscious of the possibility of one confusing the phrase 'dispensation of the Holy Spirit' with the doctrine of Dispensationalism, it ought to be stated for the avoidance of doubt that there is a slight difference in the two terms. C. I. Scofield and L. S. Chafer, protagonists of Dispensationalism, have seven dispensations, as sited by G. W. Grogan (303). These include the following: Innocence, Conscience, Human Government, Promise, Law, Grace and the Kingdom). However, for us, salvation history can only be divided into two: before and after Christ.

The four occurrences of the word dispensation (оккоvо $\mu$ เ , economy) in the KJV are found in Pauline writings: I Corinthians 9:17; Ephesians 1:10; 3:2 and Colossians 1:25. This seems to confirm the view that Paul actually perceived the period after the resurrection of Jesus Christ to be the dispensation of the Holy Spirit. In all of these passages, Paul's emphasis was on the fact that he has been entrusted with the dispensation of the Gospel of Jesus Christ. His whole life was thus committed to making explicit this Gospel. Paul saw all that came before Christ as leading to Calvary, and all that followed is meant to enable men to appropriate in their individual lives the true meaning of Calvary. Thus his sole aim in preaching to the Corinthians was to preach a Christ crucified (I Cor. 2:2).

If this is so, then one can understand why Paul's theology revolves around how the Holy Spirit can make meaningful the Cross of Christ in the lives of men. Even when he wishes to argue about the resurrection of the body in I Corinthians 15, Paul did not hesitate to predicate his submission on the fact that the transformation necessary to make man's mortal body fit for the heavenly home will be effected by the Holy Spirit. In all things therefore, the point of reference for Paul is that the Holy Spirit is God in action towards men.

\section{Paul's Concept of The Holy Spirit and The Doctrine of The Trinity Formulation of the Doctrine of the Trinity}

Having examined what Paul thinks about the Holy Spirit, it is now time to relate this to the doctrine of the Trinity. This is with a view to showing how Paul's concept of the Spirithood of God complements that of the doctrine of the Trinity.

Louis Berkhof (82) has observed that the doctrine of the Trinity has always bustled with difficulties, "and therefore it is no wonder that the Church in its attempt to formulate it was repeatedly tempted to rationalize it and to give a construction of it which failed to do justice to the scriptural data." Perhaps one reason why this has been so is that it appears that the Scriptures do not explicitly teach a doctrine of the Trinity in the precise manner of modern day systematic theology. In other words, one does not 
find in the scriptures a developed system of theology which can be referred to as Trinitarian.

However, it is perhaps right to observe that the doctrine of the Trinity is not the product of simple rational reflection on the existence of creatures in our general experience. That is to say that man in his natural setting without the aid of Scripture did not develop this doctrine. Rather, it is the product of rational reflection on those particular manifestations of the divine activity which center in the birth, ministry, crucifixion, resurrection and ascension of Jesus Christ and the gift of the Holy Spirit to the Church (Hodgson, 25). In other words, scriptural data surrounding the manifestations of God to men seem to have provided the hard core materials for a formulation of the doctrine of the Trinity.

While it is true that this doctrine is a theological doctrine derived from the special self-revelation of God, a doctrine which could not have been discovered by reason apart from that of revelation, it is pertinent to point out that from the very beginning of theological discussions of it, the use of words affected both its presentation and understanding. Hendrikus Berkhof (110) rightly posits: “The formula 'one being, three persons' from the very first moment left open several interpretations; even today it veils the problems instead of solving them."

C. F. Moule (16) made the following observation:

Whatever the methods of the patristic writers and the fathers of the Councils, we cannot today be satisfied if we are inquiring about a New Testament foundation for later creedal definitions, with anything less than evidence that the experiences reflected in the New Testament justify such definitions. What we have to ask is not, 'Are there in the New Testament expressions containing 'God', 'Christ', and 'Spirit' but 'Does New Testament experiences suggest a definition of God in terms of trinity in unity?'

The questions raised by Moule have led modern New Testament scholarship to a closer scrutiny of the data of the Scripture on the doctrine of the Trinity. It was in an attempt to interpret Scriptural data and other questions that the early Church, particularly the Patristic Fathers, developed the atmosphere for the Trinitarian controversy. According to R. S. Franks (2):

The formation of the doctrine of the Trinity will appear as an argument from history to a metaphysic as the solid basis that gives meaning to the history. It sprang from the reaction upon 
Jewish monotheism of belief in the divine mission of Jesus Christ and the experience of the power of the Holy Spirit in the Christian Church. It issued in a doctrine of One God in Three Persons, understood as an intimate knowledge of the Divine Being. The ultimate aim of the doctrine was to show how God could be both One and Three.

Church history revels that it was the Gnostics who first raised the problem of the Person of Christ in connection with God. They accepted from Christianity the belief that Jesus Christ was a Saviour, and were willing to accord Him a place in their spiritual hierarchy (Franks, 61). Some passages in the Scriptures, particularly the narratives of the baptism and crucifixion of Jesus gave the Gnostics ample chance to manipulate and develop their teachings. By the middle of the second century, the danger of Gnosticism had become both apparent and acute. It was in an attempt to forestall the apparent distortion of the Gospel message concerning Jesus Christ in relation to God by Gnostic Docetists that the Apostles' Creed (and others like it), main features of which were visible in Justin Martyr's first Apology (ca. 150 A.D.), was formulated. The Apostolic Fathers, including Polycarp, Hermas and Ignatius, further developed the defense of the Church against the Gnostics (Franks, 65-68). The Apologists, notably Aristides, Justine, Tatin, Athenagoras and Theophilus (ca. 140-180 A.D.) "made use of rational proofs for the existence of God.” (Franks, 69).

However, it was Tertullian, described both as an Anti-gnostic Father, a trenchant and potent adversary of what is known as Modalist Monarchanism, who actually pushed further a thorough discussion of the Trinity (Franks, 80). Tertullian began with the unity of God and the idea of dispensation, which the Greeks call economy (oเкоvо $\mu 1 \alpha$ ). The mystery of the economy disposes the Unity into a Trinity. Tertullian thus became the first person to use the Latin word trinitas, though Theophilus had already used the Greek equivalent tria $\$$ (Franks, 81). Tertullian taught that "the Trinity consists of Father, Son and Spirit, three not in status, but in degree." It has been aptly remarked that Tertullian's use of terminology to describe the Trinity showed some apparent inconsistency. While the terms are precise, their meaning is not always so. "Both in the doctrine of the Trinity and in that of the Incarnation, it is now the Unity and now the distinctions that prevail” (Franks, 81).

The controversy continued till the early part of the fourth century (ca. 318 A.D.). Arius, then a Presbyter of Alexandria, wanted a doctrine that would explain the origin of the universe in a way satisfactory to the Greek mind. The essence of Arianism was a form of subordination of the Son to 
the Father. He denied the eternity of Jesus Christ the Son of God as the Logos. He writes:

If the Father beget the Son, he that was begotten

had a beginning of existence: and from this it is evident that there was (a time) when the Son was not. It therefore necessarily follows, that he had his subsistence from nothing (Mikolaski, 67).

Commenting on the argument of Arius, Mikolaski agrees that "on the basis of a certain logic of terms, Arius' subordinationist theology is consistent," howbeit heretical as judged by the Apostolic witness (Mikolaski, 67). Arius was thus roundly condemned at the Council of Nicea in $325 \mathrm{AD}$. And an Anti-Arean Creed, which became a landmark in the formulation of the doctrine of the Trinity, was developed. It read in part (Franks, p.104):

We believe in One God, the Father Almighty, Maker of all things visible and invisible. And in One Lord Jesus Christ, the Son of God, begotten of the Father, only begotten, that is of the essence (ou)sia) of the Father, God of God, Light of Light, true God of true God, begotten, not made, of one essence (o(moousion) with the Father, by whom all things were made, both the things in heaven and the things on earth; who for us men and for our salvation came down and was made flesh, was made man, suffered, and died, and rose again on the third day, ascended into the heavens, and comes to judge the living and the dead. And (we believe) in the Holy Spirit.

This Creed, found at the end of his De Decratis, Athanasius devoted his whole life to defend. In his other works, he attempted to give elaborate discussions to the problem of the Trinity (Franks, 107-113). According to Mikolaski, for Athanasius, "the Scriptures teach the eternal sonship of the Logos, the direct creation of the world by God, and the redemption of the world and man by God in Christ."

\section{The Holy Spirit and the Doctrine of the Trinity}

From the wordings of the Nicean Creed, the only statement found in connection with the Holy Spirit is “And we believe in the Holy Spirit". At this stage of the argument, the Holy Spirit was not brought into the discussion of the Trinity. It was Athanasius who brought this to the open. He developed a simple fundamental argument for the divinity of the Holy Spirit: the Spirit performs certain functions and exhibits certain 
characteristics that can be ascribed only to God (Campbell, 412). The Patristic development of the doctrine of the Trinity from that point was either a movement away from or a movement towards the Athanasian position. Even in recent works, the attempt has remained largely at either defending or criticizing the Athanasian position. Athanasius made the question of the divinity of the Spirit a sine qua non of Christian theology of God. For him, "no theology can gloss over the problem presented by the Spirit, especially the issues of His divinity and His relationship to the Father and the Son" (Campbell, 438). It was Athanasius who placed the Holy Spirit at the heart of salvation activity and the very being of God.

\section{Unitarians and Trinitarians}

At present there are at least two schools of thought on this issue: the Unitarians and the Trinitarians. R. G. Crowford has given a review of arguments on both sides (282ff). While Trinitarians try to establish the doctrine of the Trinity on the basis of such passages as Matthew 28:19, John 10:30, II Corinthians 13:14 and I John 5:7-8, Unitarians reply by saying that Matthew 26:19 merely indicates that "baptism is in the name of the Father, Son and Holy Spirit, and that those who submit to this ordinance believe in the Father, the Son, and the Spirit" (Crowford, ibid.). This verse however says nothing about the equality of the three either in essence or in glory. Unitarians also maintain that John 10:30, II Corinthians 13:14 and I John 5:7-8 are all weak in supporting the co-equality of the Father, Son and Holy Spirit. According to Crowford, the first does not indicate a unity of the essence, but of will and consent. The second has the union of the names, that is Christ, God and Holy Spirit, in a single sentence but does not prove equality and identity. Finally the third is recognized by all impartial authorities to be spurious (Crowford, 282). Furthermore, H. Richard Neibhur (995) points out that there is a Unitarianism of the Father, a Unitarianism of the Son, and a Unitarianism of the Spirit. In addition to all the above, Unitarians call attention to the following as their reasons to support their insistence on the unity of the Godhead.

1. The statement of the Lord on the unity of God: "Hear, O Israel, the Lord our God is one Lord" (Mk. 12:29). This statement shows that the unity of the Divine nature which was the leading principle of Judaism held the same place in the Christian faith.

2. $\quad$ Passages like Malachi 3:6, Psalm 33:11, Hebrews 1:12, and James 1:17 show the doctrine of the immutability of God is inculcated. According to this position, if self-existence should change, it would become dependent existence and perfection would become imperfection. Yet this is what Trinitarians are guilty of doing. 
3. The doctrine of the Trinity contradicts the impassibility of God. While the Scriptures teaches that God is incapable of pain or suffering, Trinitarians appear to teach that God suffered and died. This is why Unitarians disassociate themselves from the doctrine of the Atonement, which appears to this writer to be a very serious handicap to all that Unitarians stands for, and makes it objectionable and somehow incompatible with the Christian Gospel.

Trinitarians on their part have tried to counter these arguments by the Unitarians by saying that they maintain the unity of God more than the Unitarians. While not insisting on the mathematical unity of the Godhead, they argue along with Hodgson that just as in an ideal human self there is the unity of the three activities of thinking, feeling, and willing, so it is that the revelation which God has given of Himself in history consists of these three elements "perfectly united in the divine life, and each of these elements is itself a Person." (91-95). Going further, Hodgson (95) observes that the "faith required for acceptance of the doctrine of the Trinity is faith in this unification, faith that the Divine unity is a dynamic unity actually unifying in the one Divine life the lives of three Divine Persons.”

\section{The Position of The Apostle Paul}

When we relate all the above submissions to Paul's concept of the Holy Spirit, the first thing to be noted is that, according to James D. G. Dunn (58), "the niceties of third, fourth, and fifth-century confessions and formulations about the Trinity must not be allowed to define our interpretations of Paul or force us into a clear-cut distinction between Jesus and the Holy Spirit where it does not exist in Paul.” Dunn is of the opinion that the phrase $\pi v \varepsilon v \mu \alpha \alpha \gamma \iota \omega \sigma v v \eta$ is unquestionably to be taken as a Semitic form for Holy Spirit, leading to the conclusion that Jesus' possession and experience of the Spirit is what Paul called Jesus' sonship and what later dogma has referred to as His divinity. Thus the 'deity' of the earthly Jesus is a function of the Spirit; in fact, no more and no less than the Holy Spirit.

This is not to say that Jesus became the Son of God at His baptism when the Holy Spirit is said to have descended on Him. Rather, the evidence that the life of Jesus from His very conception marked Him out as one who did not possess the Spirit by measure (John 3:34), negates the supposition that it was at His baptism that He became the Son of God. Rather, the unique work of the Holy Spirit in the life of the historical Jesus made Paul and the early Christians to refer to Jesus as the Son of God. That is to say that in the man Jesus the Holy Spirit was perfectly at work, revealing the redemptive nature of God to men, so that it is not possible to separate the Holy Spirit who was active in the life of Jesus from the Holy Spirit who is now active after His resurrection, in the life of His followers. 
Michael Green (59) and some others would not like to accept this complete identification of Jesus and the Holy Spirit. Rather, they posit that the sheer facts of experience drove the first Christians to acknowledge the deity of Yahweh, Jesus and the Spirit while distinguishing between them: "Thus, Jesus is divine, but he is not all of God that there is: he lived his earthly life in dependence on Yahweh. The Spirit is divine, marked with the very stamp of Jesus, and yet distinct: for Jesus was anointed by the Spirit, lived in the Spirit and passed His Spirit on to the Church.”

Numerous passages in the writings of Paul seem to lend support to a Trinitarian concept in the mind of Paul, giving some measure of support to the position of Green stated above. Prominent among these passages are the following which appear mainly in the opening paragraphs of the Epistles of Paul: Romans 1:7; I Corinthians 3:1; II Corinthians 1:3; 13:14; Galatians 1:1,4; Ephesians 1:2; Philippians 1:2; Colossians 1:3; I Thessalonians 1:1; II Thessalonians 1:1,2; I Timothy 1:2; II Timothy 1:2. In these passages Paul appears to make a consistent distinction between God who is "our Father" and the Lord Jesus Christ." In some instances he even refers to the Father of "Our Lord Jesus Christ.” In II Corinthians 13:14 Paul seems to have spelt out more clearly the distinction between the Persons of the Godhead when he wrote: "the grace of the Lord Jesus Christ and the love of God, and the communion of the Holy Ghost be with you all." This passage is one of the strongest testimony in the writings of Paul that he thought of the Godhead as consisting of three Persons: God the Father, God the Son, and God the Holy Spirit.

It would appear reasonable to conclude that taking a cue from such passages in Paul's writings, the Gospel writers expanded the concept of the Trinity in their writings. Thus it is clear that the concept of the Trinity finds greater support in the Gospels than in the writings of Paul, considering the fact that the writings of Paul came much earlier than the Gospels. In all however, it seems reasonable to assume, as Green has pointed out above, that the sheer facts of experience drove the first Christians to acknowledge the deity of Yahweh, Jesus and the Holy Spirit while distinguishing between their Persons.

To us, however, it would appear that the attempt at pressing the distinction in the Godhead was not uppermost in the mind of Paul. We seem to agree with Raymond Stamm (498) when he observed that for Paul "receiving the Spirit was receiving Christ Himself, and since Paul's idea of the Spirit was defined by what Jesus had said and done, he could receive the Spirit only through faith in Jesus as the Christ. The Spirit took the place of the Torah as the element of the Christ." Apparently agreeing with the position of Stamm, S. H. Hooke (378) writes that while the Gospel writers retained elements of the sporadic activity of the Spirit of Yahweh, the 
writings of Paul reveal that he made the Holy Spirit the very center of a Christian's life. Thus Weyne A. Robinson (245) is of the opinion that the Spirithood of God in the writings of Paul tend to emphasize the creative and redemptive will of personal being, realized in history in relation to the human will which God has endowed with a real, tough limited freedom. Thus the term Spirithood gathers up the great Christian doctrines, reminded Christians that while the initial fact of Christian experience is the activity of the Holy Spirit, the ultimate conception of God is that of Him as Spirit.

\section{An African Interpretation Of The Doctrine Of The Trinity}

Commenting on the utility value of the doctrine of the Trinity, C. M. LacGugna (1) has this to say:

If we move beyond venerable liturgical or dogmatic formulations about the Trinity, it is not at all obvious what it means to speak of the threefoldness of God. Certainly, Trinitarian theology is not obviously relevant for the life of most believers.

With the growth of Pentecostalism in the African society within the last sixty years, it is of utmost importance for scholars to reassess the value of the doctrine of the Trinity vis-à-vis the evangelistic work of the church in the African continent. There is no doubt that the defenders of the doctrine of the Trinity would want it accepted as a theological mystery. God Himself is a mystery and perhaps will continue to defy total understanding.

However, the million Naira question here is whether the doctrine of the Trinity as is presently explicated, is relevant to the daily living needs of most believers in this Pentecostal age, and particularly so within the third world countries? There is no doubt that the experiences of the early Christians led the Patristic Fathers to a description of God in Trinitarian terms. However, for Christians far removed from the experiences of these early Christians, does the doctrine of the Trinity really have practical spiritual significance?

It is time the Church today goes back to Paul's inclusive use of the concept of the Spirithood of God and its emphasis on the Holy Spirit as the pivot of Christian experience (Ellis, 269). Paul's concept of the Spirithood of God gives practical relevance to the Godhead. If Paul's concept of the Spirithood of God is properly understood, Christians would be able to relate with God in a more realistic and dynamic manner than with the concept of Three Persons in One God as enunciated in the Trinitarian doctrine. Robinson (245) is therefore of the opinion that to assert both the immanence and the transcendence of God, the only real basis to correlate them is afforded by the experience of the Holy Spirit, however partial: "The only 
category to which we can appeal is that of Spirit, transcending even when it includes, and indwelling by its inclusiveness."

In an effort to contextualizing the doctrine of the Trinity within the African continent, it is pertinent to take critical note of the mindset of the Africans when it comes to such abstract thinking as is required in a proper understanding of this doctrine. Bolaji Idowu (39) has rightly observed that "the Yoruba do little abstract thinking." This is true of most African tribes. The spirit world of the Africans is filled with an interaction with the Deity in one form or the other, making religion an integral part of the life of the people (Idowu, 5). Viewed from this perspective, it is obvious that the doctrine of the Trinity based on pure abstract reasoning, as is ably presented in the Athanasian Creed, will mean little or nothing to the African. This is the reason that this doctrine continues to remain an object of confusion among Christians across denominational lines in Africa. If the doctrine of the Trinity is therefore to make a direct impact on the lives of the people, scholars must come up with more pragmatic languages in which to convey their teaching on this subject.

To fulfill this objective, one has to examine more critically the Epistles of Paul. Paul believed in the essential unity that must take place between the Holy Spirit on the one hand, and the spirit of man on the other. Thus he writes in Romans 8:14 that only those who are led by the Spirit of God are the sons of God. His concept of a mystic union between the Spirit of Christ and that of man embedded in his $\varepsilon v \pi v \varepsilon v \mu \alpha \tau$ principle appears to be a fitting imagery to be used to explain the doctrine of the Trinity, both to the African and to people of other climes. According to Raymond Stamm (498) for Paul, "receiving the Spirit means receiving Christ himself.” Thus he made the Holy Spirit the very center of a Christian's life (Hooke, 378).

H. Wheeler Robinson further argues that the Spirithood of God in the writings of Paul tend to emphasize the creative and redemptive will of personal being, realized in history in relation to the human will which God has endowed with a real, though limited freedom. Thus the term Spirithood of God gathers up the great Christian doctrines, reminding Christians that while the initial fact of Christian experience is the activity of the Holy Spirit, the ultimate conception of God is that of Him as Spirit. In other words, the three Persons of the Godhead are encountered by man as Spirit.

\section{Conclusion}

It is the opinion of this writer therefore that if Paul's concept of the Spirithood of God is properly understood and taught to Christians, particularly African Christians, they would be able to relate with the Christian God in a more realistic and dynamic manner than with the concept of Three Persons in one God. In other words, while the concept of the 
Trinity is apparent in the writings of Paul, and much more so in the Gospels, the concept of the Spirithood of God in Paul's theology of the Holy Spirit gives room for a more dynamic and personal interaction between man and God.

For the African Christian to whom mystical union between man and the spirit world is a way of life, explaining the doctrine of the Trinity from the standpoint of the Spirithood of God will find ready acceptance. It is therefore being suggested that the Church today should emphasize more the concept of the Spirithood of God in which the Holy Spirit is seen as God in action towards men, serving as a complement to the concept of the Trinity, and giving the later practical and evangelical relevance. The union of the spirit of man with the Holy Spirit is what is needed for a man to have a dynamic encounter with the Trinitarian God. That is to say that the God who manifested Himself to man in the course of the three dispensations of salvation, can be encountered and enjoyed as a man becomes united with the Holy Spirit. For it is the Holy Spirit Who gives meaning and direction to a man's encounter with the Triune God.

\section{References:}

1. Berkhof, H. (1965), The Doctrine of the Holy Spirit. London: The Epmerth Press.

2. Berkhof, Louis (1981), Systematic Theology. Edinburgh: The Banner of Truth Trust.

3. Betz, Hans Dieter, (1979), Galatians. Philadelphia: Fortress Press.

4. Campbell, T. C. (1974), "The Doctrine of the Holy Spirit in the Theology of Athanasius," Scottish Journal of Theology. Volume 27, No.4.

5. Crowford, R. G. (1967), "Is the Doctrine of the Trinity Scriptural?" Scottish Journal of Theology. Volume 20, No.3.

6. Dunn, James D. G. (1973), "Flesh and Spirit: An Exposition of Romans 1:3-4,” Journal of Theological Studies, Volume 24, No. 1.

7. Ejenobo, D. T. (2016). An Afrocentric interpretation of the Holy Spirit in Pauline Theology. Saarbrucken, Germany: LAP Lambert Academic Publishing

8. Ellis, E. Earle (1973), “Christ and Spirit in I Corinthians," Christ and Spirit in the New Testament. Barnabas Lindars and Stephen S. Smalley, Editors, Cambridge: University Press, 1973

9. Franks, R. S. (1953), The Doctrine of the Trinity. London: Gerald Duckworth

10. Green, Michael (1975), I Believe in the Holy Spirit. London: Hodder \& Stoughton. 
11. Grogan, G. W. (1974). “Dispensationalism,” New International Dictionary of the Christian Church. J. D. Douglas, General Editor, Exeter: The Paternoster Press, 1974.

12. Hodgson, Leonard (1943), The Doctrine of the Trinity. London: Nisbet.

13. Hooke, S. H. (1963), "The Spirit was not yet," New Testament Studies. Volume 9, No.4.

14. Hughes, P. E. (1971), Paul's Second Epistle to the Corinthians. Michigan Wm. B. Eerdmans.

15. Idowu, E. Bolaji (1977). Olodumare: God in Yoruba Belief. London: Longman.

16. LacGugna, C. M. (1985), "Re-conceiving the Trinity as the Mystery of Salvation," Scottish Journal of Theology. Volume 38, No. 1.

17. Mikolaski, Samuel J. (1974), “Arianism'” New International Dictionary of the Christian Church. J. D. Douglas, General Editor, Exeter: The Paternoster Press, 1974.

18.

"Athanasian Creed," New

International Dictionary of the Christian Church. J. D. Douglas, General Editor, Exeter: The Paternoster Press, 1974.

19. "Trinity," New International

Dictionary of the Christian Church. J. D. Douglas, General Editor, Exeter: The Paternoster Press, 1974.

20. Moule, C. F. D. (1976), "The New Testament and the Doctrine of the Trinity: A Short Report on an Old Theme," Expository Times, Volume 78, No.1.

21. Neibhur, H. Richard (1983), “Theological Unitarianism,” Theology Today. Volume 40, No.2.

22. Pink, Arthur W. (1970), The Holy Spirit. Michigan: Baker Book House.

23. Robinson, Weyne A. (1973), I Once Spoke in Tongues. Illinois: Tyndale House.

24. Stamm, Raymond (1951), "Introduction and Exegesis to the Epistle to the Galatians," Interpreter's Bible. George A. Buttrick, General Editor, New York: Abingdon Press, Volume 10, 1951. 